\title{
Occurrence of Different Serotypes of Erysipelothrix rhusiopathiae in Retail Pork and Fish
}

\author{
By I.-M. Stenström, V. Nørrung, A. Ternström and G. Molin \\ Department of Applied Microbiology and Department of Food Technology, Chemical Center, Lund, Sweden \\ and National Veterinary Laboratory, Copenhagen, Denmark.
}

\begin{abstract}
Stenström I.-M., V. Nørrung, A. Ternström and G. Molin: Occurrence of different serotypes of Erysipelothrix rhusiopathiae in retail pork and fish. Acta vet. scand. 1992, 33, 169-173. - Retail pork ( 38 samples), cod (10 samples) and herring (10 samples) were obtained from 12 stores in the area of Lund in southern Sweden during September and October 1990. Erysipelothrix rhusiopathiae was isolated from $50 \%$ of the pork samples, $60 \%$ of the cod samples and from $30 \%$ of the samples from herring. Serotype 2 dominated on retail pork as well as on fish samples constituting $53 \%$ of the pork isolates (10 strains) and $33 \%$ of the cod isolates ( 2 strains). All E. rhusiopathiae isolates originating from herring were serotype 2 ( 3 strains). Serotypes $1 \mathrm{~b}, 6$, and 8 were isolated from retail pork only (6,2 and 1 strains, respectively). Serotype 5 was isolated from cod only (3 strains) and so was serotype 9 (1 strain). The public health hazards with the occurrence of virulent strains of Erysipelothrix rhusiopathiae in retail pork and fish are discussed.
\end{abstract}

cod; herring.

\section{Introduction}

Erysipelothrix rhusiopathiae is the bacteria responsible for swine erysipelas, the economic importance of which is reflected by the frequent use of vaccine in swine producing countries to control the disease (Wood 1984). According to Swedish legislation (Anon. 1990) any carcass on which E.rhusiopathiae is found must be destroyed. Anyhow, the occurrence of E.rhusiopathiae on pork directly from the cutting lines in some Swedish slaughter houses was reported by Ternström \& Molin (1987) and Molin et al. (1989). E. rhusiopathiae has also been found on Japanese retail pork (Shiono et al. 1990).

Since the antigenic heterogeneity within $E$. rhusiopathiae was first observed (Watts 1940) 26 serotypes have been described (Nørrung \& Molin 1991). Although several serotypes have been isolated from diseased animals, serotypes 1 and 2 are considered the most prevalent associated with Erysipelothrix infections in swine (Eamens 1988, Takahashi et al. 1985). E.rhusiopathiae has also been frequently isolated from fish (Shewan 1971) but reports concerning serotypes are scanty (Hashimoto et al. 1974).

In the pre-penicillian era E.rhusiopathiae was known as a common agent of infections in humans causing erysipelas in its acute phase and with arthritis and endocarditis as more rare complications (Eissner \& Ewald 1973). Erysipelas is still considered an occupational disease affecting people handling meat and fish (Salamah 1988, Reboli \& Farrar 1989). E. rhusiopathiae is however also considered an opportunistic pathogen and findings of the bacteria are reported from old and debilitated patients (Simerkoff \& Rahal 1973, Papachristos 1987, Potvliege \& Hansen 
1989). The aim of this study was to elucidate the distribution of various serotypes of $E$. rhusiopathiae on retail pork and fish from a local area in southern Sweden.

\section{Materials and methods \\ Sampling}

Raw pork and fish were purchased during September and October 1990 from various local stores in Lund, Sweden. Cutlets of pork were cut from the end of whole pork loins and only 1 section surface per sample was made. In total, 38 cutlets were sampled from 9 stores. Twenty fish samples from 5 different stores were taken (10 cods and 10 herrings). Only 2 stores sold both pork and fish.

\section{Isolation}

From each cutlet 2 meat samples were taken from the partly lardy longitudinal muscle surface using a cork borer (radius $1 \mathrm{~cm}$ ). The cross-sectioned surfaces were sampled using a cotton-swab. The swab was transferred to a test tube with $8 \mathrm{ml}$ of Wood's selective enrichment medium (Wood 1965) together with the 2 meat samples. The tubes were incubated for 5 days at $37^{\circ} \mathrm{C}$. After 2 and 5 days $10 \mathrm{ml}$ of the medium was inoculated on blood agar plates (blood agar base supplemented with $4 \%$ horse blood) which were incubated for $1-5$ days at $37^{\circ} \mathrm{C}$. Colonies with weak zones of $\beta$-hemolysis were transferred to Brain Heart Infusion agar plates (BHI, Oxoid; $37^{\circ} \mathrm{C}$; 2d) and then examined for Gram reaction (Gregersen 1978), morphological characteristics and motility (phase contrast microscopy), catalase and $\mathrm{H}_{2} \mathrm{~S}$ production (Molin et al. (1989). Gram positive, catalase negative, non motile rods with positive $\mathrm{H}_{2} \mathrm{~S}$ reaction were considered E.rhusiopathiae.

From each fish sample 2 cork borer samples
Table 1. Incidence of Erysipelothrix rhusiopathiae on raw pork and fish for consumption.

\begin{tabular}{lcc}
\hline Origin & $\begin{array}{c}\text { Number of } \\
\text { samples }\end{array}$ & $\begin{array}{c}\text { Percentage of } \\
\text { positive samples }\end{array}$ \\
\hline Pork & 38 & 50 \\
Cod & 10 & 60 \\
Herring & 10 & 30 \\
\hline
\end{tabular}

were taken from the anterior part of the fish. The cotton-swab samples were taken both from the skin and from the muscle surface. The samples were then treated in the same way as the meat samples.

\section{Serotyping}

Isolated strains were serotyped by agar gel precipitation tests as described by Nørrung et al. (1987).

\section{Results and discussion}

In total 57 E.rhusiopathiae strains were isolated from 19 pork samples and 9 fish samples (Table 1). E. rhusiopathiae was isolated from $30-60 \%$ of the samples. Only 1 isolate from each E.rhusiopathiae positive pork and fish sample was serotyped, i.e. 28 strains in total (Table 2).

Serotype 2 was the dominating serotype on pork and was isolated also from herring and cod (Table 2). It constituted $53 \%$ of the pork isolates and $56 \%$ of the fish isolates (Table 2 ). Serotype 2 has previously been isolated from healthy and diseased slaughter pigs and from pig slurries (Nørrung et al. 1987, Joo et al. 1988, Takahashi et al. 1984, 1987, 1989). It has also been found on pork loins from a Swedish slaughter house (Molin et al. 1989) and in Japanese retail raw pork (Shiono et al. 1990). Pathogenicity tests have shown that serotype 2 strains are highly virulent for mice (Molin et al. 1989, Shiono et al. 1990) and 
Table 2. Distribution of different serotypes of Erysipelothrix rhusiopathiae on raw pork and fish for consumption

\begin{tabular}{lcrcccc}
\hline \multirow{2}{*}{ Origin } & \multicolumn{6}{c}{ Number of strains belonging to serotype } \\
\cline { 2 - 7 } & $1 \mathrm{~b}$ & 2 & 5 & 6 & 8 & 9 \\
\hline Pork & 6 & 10 & & 2 & 1 & \\
Cod & & 2 & 3 & & & 1 \\
Herring & & 3 & & & & \\
\hline In total: & 6 & 15 & 3 & 2 & 1 & 1 \\
\hline
\end{tabular}

pigs (Takahashi et al. 1987, 1989, Eamens \& Nicholls 1989).

Serotype $1 \mathrm{~b}$ was isolated from $32 \%$ of the pork samples in the present study (Table 2) and was thereby about 4 times more frequent than in Japanese retail raw pork (Shiono et al. 1990). However, Takahashi et al. (1984, 1989) isolated several serotype $1 \mathrm{~b}$ strains from both healthy and diseased pigs and in Australia it was found to be the most common serotype associated with diseased pigs, sheep and poultry (Eamens et al. 1988). Mice as well as pig pathogenicy has been demonstrated within serotype 1b strains (Shiono et al. 1990, Takahashi et al. 1989).

The 3 strains of serotype 5 isolated in the present study all originated from cod (Table 2 ). Serotype 5 has previously been reported from outbreaks of erysipelas in poultry (Bisgaard et al. 1980) and from healthy and diseased swine, fish body surfaces (Lamont 1979, Takahashi et al. 1985) and from diseased sheep (Eamens et al. 1988). Takahashi et al. (1985) demonstrated varying mice pathogenicity of serotype 5 strains.

In the present study serotypes 6 and 8 were represented by 2 and 1 strains from pork, respectively (Table 2). Highly virulent, mice pathogenic strains belonging to serotypes 6 and 8 were isolated from slaughter pigs with chronic erysipelas by Takahashi et al. (1984, 1985).

The remaining serotype 9 strain in the present study was isolated from cod (Table $2)$. Together with serotypes 1,5 and 6 , serotype 9 has been shown to be the most prevalent in outbreaks of erysipelas in poultry in Denmark (Bisgaard et al. 1980). Serotype 9 has also been proved to be mice pathogenic (Shiono et al. 1990).

Occupational exposure to animals, meat or fish are often revealed in the anamnesis of patients suffering from infections with $E$. rhusiopathiae (Simerkoff \& Rahal 1973, Ryan 1982, Normann \& Kihlström 1985). Although infections with $E$. rhusiopathiae in human are still reported, there is no information concerning serotypes involved.

Virulent E. rhusiopathiae strains are widely distributed within apparently healthy animals as well as within pork and fish for consumption. Although present in numbers which necessitate an enrichment before isolation, there is an obvious risk that the consumers will become infected with virulent $E$. rhusiopathiae strains from retail pork and fish. To our knowledge pathogenic serotypes of E.rhusiopathiae have never before been reported from Swedish retail fish.

\section{Acknowledgments}

This study was supported by the Swedish Work Environment Fund. Ms Ann Barthel and Ms Ella Hytting are thanked for skillful technical assistance.

\section{References}

Anonymous: Statens Livsmedelsverks Författningssamling SLV FS (Swedish Food Regulations issued by the Swedish National Food Administration) $1990,6$.

Bisgaard M, Nørrung V, Tornøe N: Erysipelas in poultry. Prevalence of serotypes and epidemiological investigations. Avian Pathol. 1980, 9, 355-362. 
Eamens $G J$ : Pathogenicity of field isolates of Erysipelothrix rhusiopathiae in mice, rats and pigs. Aust. vet. J. 1988, 65, 280-284.

Eamens $G J$, Nicholls $P J$ : Comparison of inoculation regimes for the experimental production of swine erysipelas arthritis I. Clinical and bacteriological findings. Aust. vet. J. 1989, 66, 212-216.

Eamens $G J$, Turner $M J$, Catt $R E$ : Serotypes of Erysipelothrix rhusiopathiae in Australian pigs, small ruminants, poultry, and captive wild birds and animals. Aust. vet. J. 1988, 65, 249-252.

Eissner $G$, Ewald $F$ W: Rotlauf. (Erysipelas). Veb Gustav Fischer Verlag Jena, 1973, 141-145.

Gregersen T: Rapid method for distinction of Gram-negative from Gram-positive bacteria. European J. appl. microbiol. Biotechnol. 1978, 5, 123-127.

Hashimoto K, Yoshida Y, Sugawara H: Serotypes of Erysipelothrix rhusiopathiae isolated from swine, fish, and birds in Japan. Nat. Inst. Anim. Hlth Quart. 1974, 14, 113-120.

Joo Y S, Park Y H, Park J M, Kang S W: Studies on serotypes of Erysipelothrix rhusiopathiae isolated from pigs. Res. Rep. Rural. Dev. Adm. (SUWEON) 1988, 30, 45-50.

Lamont M H: Erysipelothrix rhusiopathiae: epidemiology and infection in sheep. Vet. Bulletin. 1979, 49, 479-495.

Molin G, Söderlind 0, Ursing J, Nфrrung V, Ternström A, Löwenhielm C: Occurrence of Erysipelothrix rhusiopathiae on pork and in pig slurry, and the distribution of specific antibodies in abattoir workers. J. appl. Bacteriol. 1989, 67, 347-352.

Norrmann B, Kihlström E: Erysipelothrix rhusiopathiae septicaemia. Scand. J. infect. Dis. 1985, 17, 123-124.

Nørrung V, Molin G: A new serotype of Erysipelothrix rhusiopathiae isolated from pig slurry. Acta vet. Hungaria 1991, 39, 137-138.

Nørrung V, Munch B, Larsen H E: Occurrence, isolation and serotyping of Erysipelothrix rhusiopathiae in cattle and pig slurry. Acta vet. scand. 1987, 28, 9-14.

Papachristos T: Letters to the editors. Clin. Microbiol. Newsl. 1987, 9, 187-188.

Potvliege C, Hansen W: Erysipelothrix rhusiopathiae septicemia. Clin. Microbiol. Newsl. 1989, 11, 30-32.

Reboli A C, Farrar W E: Erysipelothrix rhusiopathiae: An occupational pathogen. Clin. Microbiol. Reviews 1989, 2, 354-359.
Ryan K J: Erysipelothrix infections. In: Wedgewood $\mathrm{R} \mathbf{J}$ et al. (Eds): Infections in children. Harper \& Row Publishers, Philadelphia 1982.

Salamah $A$ A: Isolation of Erysipelothrix rhusiopathiae from a 55 year old man and a positive tracing of the infection to chicken-raising premise. Microbiologica 1988, 11, 169-171.

Shewan $J$ M: The microbiology of fish and fishery products - a progress report. J. appl. Bact. 1971, 34, 299-315.

Shiono H, Hayashidani H, Kaneko K-I, Ogawa M, Muramatsu $M$ : Occurrence of Erysipelothrix rhusiopathiae in retail raw pork. J. Food Protect. $1990,53,856-858$.

Simerkoff $M S$, Rahal Jr J J: Acute and subacute endocarditis due to Erysipelothrix rhusiopathiae. Amer. J. med. Sci. 1973, 266, 53-57.

Takahashi T, Sawada T, Muramatsu M, Tamura Y, Fujisawa T, Benno Y, Mitsuoka T: Serotype, antimicrobial susceptibility, and pathogenicity of Erysipelothrix rhusiopathiae isolates from tonsils of apparently healthy slaughter pigs. J. clin. Microbiol. 1987, 25, 536-539.

Takahashi T, Sawada T, Takagi M, Seto K, Kanzaki $M$, Maruyama $T$ : Serotypes of Erysipelothrix rhusiopathiae strains isolated from slaughter pigs affected with chronic erysipelas. Jap. J. vet. Sci. 1984, 46, 149-153.

Takahashi T, Sawada T, Seto K, Muramatsu M, Maruyama T, Kanzaki M: Pathogenicity of Erysipelothrix rhusiopathiae strains of serovars $1 \mathrm{a}$, $3,5,6,8,11,21$, and Type $\mathrm{N}$ isolated from slaughter pigs affected with chronic erysipelas. Jap. J. vet. Sci. 1985, 47, 1-8.

Takahashi T, Zarkasie K, Mariana S, Sumadi, Ogata $M$ : Serological and pathogenic characterization of Erysipelothrix rhusiopathiae isolates from tonsils of slaughter pigs in Indonesia. Vet. Microbiol. 1989, 21, 165-175.

Ternström A, Molin G: Incidence of potential pathogens on raw pork, beef and chicken in Sweden, with special reference to Erysipelothrix rhusiopathiae. J. Food Protect. 1987, 50, 141146.

Watts P S: Studies on Erysipelothrix rhusiopathiae. J. Path. Bact. 1940, 50, 355-369.

Wood $R$ L: A selective liquid medium utilizing antibiotics for isolation of Erysipelothrix rhusiopathiae. Amer. J. vet. Res. 1965, 26, 1303-1308.

Wood $R$ L: Swine erysipelas - a review of prevalence and research. J. Amer. vet. Med. Assoc. 1984, 184, 944-949. 


\section{Sammanfattning}

Förekomst av olika serotyper av Erysipelothrix rhusiopathiae isolerade från griskött och färsk fisk som inköpts i livsmedelsbutiker $i$ Lund med omnejd. Griskött (38 prov), torsk (10 prov) och sill (10 prov) inhandlades under september och oktober 1990 i 12 butiker i Lundatrakten med manuella kött- respektive fiskdiskar. Erysipelothrix rhusiopathiae isolerades från $50 \%$ av proverna från gris, $60 \%$ från torsk samt från $30 \%$ av sillproverna. Ett E.rhusiopathiae-isolat från varje positivt kött- resp fiskprov serotypades. Serotyp 2 dominerade bland kött- såväl som fiskisolaten och utgjorde $53 \%$ av isolaten från gris och $33 \%$ av torskisolaten. Samtliga E.rhusiopathiae-isolat från sill tillhörde serotyp 2. Av övriga serotyper återfanns $1 \mathrm{~b}, 6$ och 8 på griskött medan serotyp 5 och 9 hittades på torsk.

Samtliga dessa serotyper har i litteraturen beskrivits som virulenta för möss och svin. Risken för konsumenter att exponeras för E. rhusiopathiae diskuteras.

(Recived January 2, 1992; accepted January 6, 1992).

Reprints may be requested from: Inga-Maj Stenström, Department of Applied Microbiology, Chemical Center, P. O. Box 124, S-221 00 Lund, Sweden. 